See discussions, stats, and author profiles for this publication at: https://www.researchgate.net/publication/329334157

\title{
Creating shared spaces: developing teaching through peer supervision
}

Article in Mind Culture and Activity · November 2018

Dol: 10.1080/10749039.2018.1544645

\section{CITATIONS}

0

2 authors:

70. Thomas de Lange

University of Oslo

20 PUBLICATIONS 76 CITATIONS

SEE PROFILE

\section{READS}

91

Line Wittek

University of Oslo

33 PUBLICATIONS 100 CITATIONS

SEE PROFILE

Some of the authors of this publication are also working on these related projects:

Higher Education Learning Outcomes HELO View project

Faculty peer tutoring in teaching and supervision - Innovating teacher collaboration practices in Norwegian higher education (PeTS) View project 


\title{
Creating shared spaces: developing teaching through peer supervision
}

\author{
Thomas de Lange and Line Wittek \\ University of Oslo
}

To cite this article: Thomas de Lange \& Line Wittek (2018): Creating shared spaces: developing teaching through peer supervision, Mind, Culture, and Activity, DOI: 10.1080/10749039.2018.1544645

\begin{abstract}
This article examines how university teachers from different disciplines and faculties collaborate by giving feedback on each other's teaching. This collaborative activity, termed Peer Supervision Groups (PSG), is part of a faculty development course at a Norwegian university. Conceptually the study draws on activity theoretical notions of boundary crossing and boundary objects and is empirically based on observations of a PSG over a period of six months. The article examines how collaborative interactions about teaching across communities emerge in the PSG setting and how this arrangement can be improved for the benefit of developing teaching practices in higher education.
\end{abstract}

\section{Introduction}

Peer-based feedback on teaching, which has been practiced in various ways in higher education institutions globally, is generally implemented as an incentive to support teachers to handle challenges, as well as to motivate teaching staff to experiment creatively to improve their teaching (Price, Handley, \& Millar, 2011). Involving peers in feedback groups of this sort is argued to serve two specific purposes. First, peers familiar with teaching demands and challenges are in a position of comprehending described, as well as observed, teaching and this allows them to provide relevant and useful feedback (Curlette \& Granville, 2014).

Second, the role of being a peer is generally not connected to a higher position of power. Symmetric relations can be an opportunity for the trust considered vital for opening up the intimate space of the classroom and allowing for productive and supportive discussions about teaching (de Lange \& Lauvås, 2018).

This article presents an empirical analysis of how university teachers engage in a specific peer-based feedback arrangement at a Norwegian university. The arrangement, called a peer supervision group (PSG), is part of a faculty development course where peers 
collaborate across faculty boundaries by observing and giving feedback on classroom teaching. An aim of this activity is to provide an opportunity for teachers to reflect on their own teaching practices, as well as develop approaches to teaching based on feedback and reflective discussions.

Based upon activity theory (Engeström 2015), we conceptualize the PSG as a boundary zone with a set of mediating artifacts, arrangements and resources as essential boundary objects. Analytically, we implement Mercer's $(1995,2000)$ three-part typology of disputational, cumulative, and exploratory talk with the purpose of identifying how the boundary objects enable and constrain cross-disciplinary discussions about teaching in this PSG setting (Akkerman \& Bakker, 2011; Tsui \& Law, 2007). This research is guided by the following research questions: 1) What significance do the boundary objects hold in the PSG discussions?; 2) What obstacles and opportunities emerge in this PSG arrangement?

Structured in 6 sections, the first section reviews research into peer-based feedback on teaching in higher education. The second section provides a theoretical introduction to boundary objects as mediational artifacts within the scope of cultural-historical activity theory. The third section offers description of the PSG arrangement and core artifacts implemented as boundary objects in this setting. Here we also describe the methods for our research, based on a qualitative design and interaction analysis of observed PSG discussions. The fourth section is an analysis of two selected episodes that display participants' talk. The fifth section discusses the role and value of shared spaces for discussions regarding teaching in higher education. The sixth section is a conclusion with practical implications for the PSG activity and future research on peer-based feedback.

\section{Research on peer-based teacher feedback in higher education}

Although a safe environment in peer-based feedback generally is a priority, many teachers still feel apprehensive when being observed (Martin, Prosser, Trigwell, Ramsden, \& 
Benjamin, 2000). To handle this vulnerability, university programs involving peer-based feedback on teaching may organize peer groups across disciplines and departmental affiliations (Lauvås, Lycke \& Handal, 2016). This cross-disciplinary arrangement allows participants to address problems in their local working environment anonymously without the fear of exposing colleagues or superiors (Hammersly-Fletcher \& Orsmond, 2005; Thomas et al., 2014). A supplemental effect of collegial distance is that peers from other disciplines, familiar enough with general rules and expectations for teaching, need access to the particularities of peers' teaching contexts to be able to provide productive feedback. This serves the purpose of explaining implicit rules, conventions, and ideas often taken for granted in various disciplines (Donnelly, 2007).

Further, inviting peers from various backgrounds also acknowledges the diversity of strategies and approaches and may lead to the elaboration of the participants' teaching repertoires (Thomas et al., 2014). This diversity creates a collaborative space for sharing a variety perspectives on teaching, as well as mirroring the participants' established approaches with alternative views (Ferrado, 2000). Several empirical studies have also confirmed that establishing this kind of intermediate community of peers is highly appreciated (Costa \& Kallik, 1993; Kohut, Burnap, \& Yon, 2007).

While literature on collaborative peer groups in higher education teaching has primarily focused on organizational frameworks (Lauvås, Lycke \& Handal, 2016), what has been less frequently addressed is how cross-disciplinary differences are handled in these settings. Cross-disciplinarity concerns a balance between, on the one hand, respecting selective autonomy on the receiving end of feedback, while simultaneously allowing honest feedback in providing opinions about observed teaching (Ajjawi \& Boud, 2015; Price, Handley, \& Millar, 2011; Utheim-Steen \& Wittek, 2017). In addition, while most peer feedback is based on rules and conventions attempting to safeguard a productive balance of 
dialogue, empirical studies of how such conventions are acted upon is scarce (Scaratti, Ivaldi \& Frassy, 2017). How supportive frameworks accommodate dialogue and how peers discursively create meaning from each other's teaching — hence, how the boundary zone between peers' practices is constructed discursively in this kind of setting - have to our knowledge, not been previously addressed though empirical analysis.

\section{Theoretical framework}

Mediating artifacts such as concepts, tools, norms, plans, techniques, and strategies represent knowledge resources that, through their use, create a common ground for actions and interactions in communities of practice (Vygotsky, 1987). In activity theory, the notion of object also adds a dimension of meanings and motivations in the use of artifacts toward the outcomes of the social activity (Jahreie \& Ludvigsen, 2007). The notion of object accentuates the interrelation between artifact use and collective meaning-making (de Lange, 2011; Engeström \& Sannino, 2010).

Organizations, such as universities, are defined as relatively independent activity systems with permanent members, an established division of labor, longitudinal role and norm structures, and more or less well-defined long-term objectives for work-related activities (Engeström, 2015). In larger universities, different faculties and departments also appear as a complex web of autonomous interrelated communities (Roos, 2012). Conversely, the focus in the PSG setting reported here is to establish a common ground for discussing teaching across boundaries, thus, highlighting conceptions of boundary objects and boundary zone. According to Abraham et al. (2015), boundary objects are "abstract or physical artifacts that support coordination among different communities of practice by providing common ground" (p. 4). This definition highlights the explicit effort in creating sameness based on difference, or what Tsui and Law (2007) have described as boundary zones. 
A boundary zone is a "place where elements from (different) activities are presented, [...] meet, and form new meanings" (p. 1290). Where difference is a value, awareness and benefit can be gained when actors meet across boundaries. Boundary zone is here related to the value of difference and the benefit of approaching difference across practices by creating a shared space for learning and development. In this sense, a boundary zone based on differences at the same time creates sameness where knowledge is being shared (Scaratti, Ivaldi, \& Frassy, 2017). However, working across boundaries is not straightforward and often requires artifacts that aid interactions. These mediating artifacts, or boundary objects (Akkerman \& Bakker, 2011; Konkola, Tuomi-Gröhn, Lambert, \& Ludvigsen, 2007; Lambert, 2003b), are intended to guide and support the participants' collaborative efforts in the boundary zone (Rantavuori, Engeström \& Lipponen, 2016).

In this study, a set of boundary objects was incorporated into a PSG activity to aid cross-disciplinary collaboration and reflection. The focus of our analysis was to study how these boundary objects enabled the participants to engage collaboratively and explore shared notions about teaching.

\section{Context and methods}

The focus of this article is on one PSG in a professional development course that included 100 working hours over one calendar year, with a research-based focus on student learning, teaching development, and supervision in higher education. The PSG activity, the specific focus in this paper, comprised about $25 \%$ of the course and included inviting peers to visit, observe, discuss, and give feedback on each other's teaching in groups of 4-5 people. The activity included participants from different faculties and disciplines in groups that were pre-arranged to ensure diversity in academic backgrounds. The groups were organized and introduced to the activity during a two-day seminar at the beginning of the professional development course. 
The PSG activity was organized around a set of artifacts that were important both in how the participants arranged their meetings and observations, and how they prepared and engaged in discussions. We refer to these artifacts as boundary objects (see Table 1).

Table 1: Overview of artifacts related to the PSG activity

\begin{tabular}{|l|l|l|}
\hline Artifact 1 & $\begin{array}{l}\text { Temporal } \\
\text { sequencing of PSG }\end{array}$ & $\begin{array}{l}\text { Purpose } \\
\text { primarily by coordinating the participants' actions }\end{array}$ \\
\hline Artifact 2 & $\begin{array}{l}\text { Tasks and roles in } \\
\text { the PSG }\end{array}$ & $\begin{array}{l}\text { Create division of labor in the group and allocate sufficient time for } \\
\text { boundary-crossing discussions of educational programs and teaching }\end{array}$ \\
\hline Artifact 3 & $\begin{array}{l}\text { Written teaching } \\
\text { memos in the PSG }\end{array}$ & $\begin{array}{l}\text { Create space for boundary crossing interactions around each teaching } \\
\text { session across disciplinary contexts }\end{array}$ \\
\hline Artifact 4 & $\begin{array}{l}\text { Concepts from the } \\
\text { introductory course }\end{array}$ & $\begin{array}{l}\text { Create shared conceptual grounding and knowledge space for discussing } \\
\text { teaching across disciplinary boundaries }\end{array}$ \\
\hline
\end{tabular}

Together, these artifacts were intended to contribute to a context for the PSG to enable and sustain horizontal boundary-crossing interactions, as described in the following.

Artifact 1 - Temporal sequencing of PSG activity: The temporal sequencing concerned how the PSG worked within a timetable. This sequencing was important for ensuring that plans were presented in due time before the observations and feedback discussions, which immediately followed classroom observations, as illustrated in Figure 2.

\begin{tabular}{|c|c|c|c|c|c|c|c|}
\hline $\begin{array}{c}\text { Make } \\
\text { appointments }\end{array}$ & $\begin{array}{l}\text { Write/send } \\
\text { preparation } \\
\text { memo }\end{array}$ & $\begin{array}{c}\text { Pre- } \\
\text { observation } \\
\text { meeting }\end{array}$ & $\begin{array}{c}\text { First } \\
\text { classroom } \\
\text { observation }\end{array}$ & $\begin{array}{l}\text { First feed- } \\
\text { back } \\
\text { discussion }\end{array}$ & $\begin{array}{l}\text { Second } \\
\text { classroom } \\
\text { observation }\end{array}$ & $\begin{array}{l}\text { Second } \\
\text { feed-back - } \\
\text { discussion }\end{array}$ & - \\
\hline
\end{tabular}

Figure 2: Temporal sequencing of PSG meetings (Artifact 1)

The main purpose was to ensure that all participants were given time to discuss teaching memos and plans, classroom visits, and feedback immediately after observations. In this way, Artifact 1 created a shared temporal sequence for the group members.

Artifact 2 - Tasks and roles in the PSG's: Artifact 2 reflected duties and roles shared by group members: observee, main supervisor, and third party observer. This arrangement 
ensured that all group members, including the observee and main supervisor, joined

discussions with their critical reflections (see Table 2).

Table 2: Tasks and roles in the PSG activity (Artifact 2)

\begin{tabular}{|l|l|l|}
\hline Organization & Description & Purpose \\
\hline 1. Preparation memo & $\begin{array}{l}\text { Each participant writes a short memo (approximately one } \\
\text { page) specifying: } \\
\text { Background information } \\
\text { Teaching aims for the session } \\
\text { What the teacher plans to do in the classroom } \\
\text { What they want the observers to attend to }\end{array}$ & $\begin{array}{l}\text { Provide condensed } \\
\text { information about the } \\
\text { selected lesson that can } \\
\text { be discussed further in } \\
\text { the group }\end{array}$ \\
\hline $\begin{array}{l}\text { 2. Pre-observation } \\
\text { meeting }\end{array}$ & $\begin{array}{l}\text { The meeting starts by appointing main supervisors for } \\
\text { each member. Then, each memo is discussed with an } \\
\text { emphasis on: } \\
\text { Clarifying and adding information, problematizing } \\
\text { planned teaching } \\
\text { Clarifying whether the session is an experiment or } \\
\text { common practice etc. }\end{array}$ & $\begin{array}{l}\text { Provide support in } \\
\text { planning teaching } \\
\text { sessions and critically } \\
\text { discussing ideas/ } \\
\text { experiences about } \\
\text { teaching }\end{array}$ \\
\hline $\begin{array}{l}\text { 3. Teaching } \\
\text { observation }\end{array}$ & $\begin{array}{l}\text { Observe teaching based on memo and discussion in pre- } \\
\text { observation meeting } \\
\text { Note unforeseen aspects that emerge in the teaching } \\
\text { session }\end{array}$ & $\begin{array}{l}\text { Provide structure and } \\
\text { focus by basing } \\
\text { observations on first two } \\
\text { stages of PSG's work, } \\
\text { including unpredicted } \\
\text { aspects }\end{array}$ \\
\hline 4. Feedback discussion & $\begin{array}{l}\text { The group gathers for discussion of the observed session: } \\
\text { The observed teacher starts by describing their } \\
\text { experience; the main supervisor follows by giving } \\
\text { feedback; other group members join the discussion with } \\
\text { their own observations }\end{array}$ & $\begin{array}{l}\text { Describe own } \\
\text { experiences, present } \\
\text { observations and } \\
\text { reflections, explore } \\
\text { alternative approaches }\end{array}$ \\
\hline
\end{tabular}

This mediating artifact was intended to distribute roles and responsibilities in the group, which would ensure a dedicated focus on each group member, as well as a structure for participants' interactions.

Artifact 3 - Written teaching memos: The third artifact was written descriptions of the lessons presented to the group. These memos provided information on subject, context, student population and the objectives of the lesson. Each memo also contained notes 
regarding uncertainties, areas of inquiry, and requests for specific forms of feedback. Table 3

provides an overview of memos for the observed group (pseudonyms have been used).

Table 3: Overview of written memos in the observed PSG

\begin{tabular}{|c|c|c|c|}
\hline Participant & Affiliation/field & Observed teaching session & Feedback request \\
\hline $\begin{array}{l}\text { Andrew, } \\
\text { Associate } \\
\text { Professor }\end{array}$ & $\begin{array}{l}\text { Music sciences, } \\
\text { Faculty of Mathematics } \\
\text { and Natural Sciences } \\
\text { (Informatics) } \\
\text { Specialization in music } \\
\text { technology, acoustics, } \\
\text { sound theory, and } \\
\text { programming }\end{array}$ & $\begin{array}{l}\text { Course name: Interactive music } \\
\text { Audience/population: Bachelor students, } \\
\text { music technology (20). } \\
\text { Observation: Introduction lecture } \\
\text { Lecture content: Presenting an overview } \\
\text { of the course, introduction to sensors in } \\
\text { interactive music systems with illustrative } \\
\text { demonstrations }\end{array}$ & $\begin{array}{l}\text { Asked fellow observers } \\
\text { to attend to his } \\
\text { communication with } \\
\text { students (“Am I } \\
\text { progressing too fast, } \\
\text { catching their interest, } \\
\text { and connecting with the } \\
\text { students?") }\end{array}$ \\
\hline $\begin{array}{l}\text { John, } \\
\text { Professor }\end{array}$ & $\begin{array}{l}\text { Medical Behavioral } \\
\text { Sciences, Faculty of } \\
\text { Medicine } \\
\text { Specialization in } \\
\text { clinical disciplines and } \\
\text { infectious diseases } \\
\text { Teaches medical } \\
\text { students in both small } \\
\text { groups and lectures }\end{array}$ & $\begin{array}{l}\text { Observation: Conference presentation } \\
\text { (conducted after finishing semester } \\
\text { teaching) } \\
\text { Audience/population: Mainly infectious } \\
\text { disease specialists. The number attending } \\
\text { is unclear, expects to fill a medium-sized } \\
\text { lecture hall } \\
\text { Lecture content: Trypanosomiasis/sleeping } \\
\text { sickness and prospects of handling the } \\
\text { disease in the future }\end{array}$ & $\begin{array}{l}\text { Especially interested in } \\
\text { feedback on his ability } \\
\text { to engage the audience } \\
\text { by telling stories and } \\
\text { using a manometer } \\
\text { system } \\
\text { Concerned about } \\
\text { overloading the } \\
\text { audience }\end{array}$ \\
\hline $\begin{array}{l}\text { Peter, } \\
\text { Professor }\end{array}$ & $\begin{array}{l}\text { Political Science and } \\
\text { Health Politics, Faculty } \\
\text { of Medicine } \\
\text { Teaches mainly in } \\
\text { Bachelor's program in } \\
\text { health organization, } \\
\text { management, and } \\
\text { health politics }\end{array}$ & $\begin{array}{l}\text { Course context: Open day conference } \\
\text { describing the Bachelor's program for } \\
\text { visiting students } \\
\text { Audience/population: Visiting high school } \\
\text { students (15-20) } \\
\text { Lecture content: The lecture is an arena to } \\
\text { promote the Bachelor's program for } \\
\text { potential students starting at the university } \\
\text { next semester. Focus on presenting course } \\
\text { aims/content }\end{array}$ & $\begin{array}{l}\text { Asked for feedback on } \\
\text { whether he is } \\
\text { communicating well } \\
\text { with the audience, } \\
\text { conveying the } \\
\text { complexities of the field } \\
\text { to inexperienced } \\
\text { listeners, and catching } \\
\text { their attention }\end{array}$ \\
\hline $\begin{array}{l}\text { Kate, } \\
\text { Associate } \\
\text { Professor }\end{array}$ & $\begin{array}{l}\text { Sociology and welfare } \\
\text { society, politics and } \\
\text { state regulations, } \\
\text { Faculty of Social } \\
\text { Sciences } \\
\text { Teacher, head of } \\
\text { Master's -level course } \\
\text { in work-life and social } \\
\text { affairs }\end{array}$ & $\begin{array}{l}\text { Course context: Course organized into } \\
\text { intensive units for a duration of 6-7 } \\
\text { weeks, with 2-3 lectures per week } \\
\text { Audience/population: } 12 \text { Master's-level } \\
\text { students } \\
\text { Lecture content: Introductory lecture to } \\
\text { the course addressing welfare state } \\
\text { principles, challenges, and theories }\end{array}$ & $\begin{array}{l}\text { Asked for feedback on } \\
\text { PowerPoint use, whether } \\
\text { she succeeds in creating } \\
\text { an inclusive learning } \\
\text { environment in which } \\
\text { students dare to engage } \\
\text { and ask questions }\end{array}$ \\
\hline
\end{tabular}

The overview of the memos (see Table 3) displays, in part, how the group members introduced one another to their teaching before the first PSG meeting. These memos were 
intended to create a common ground for discussing each lesson across the PSG meetings regardless of disciplinary grounding.

Artifact 4 - Conceptual notions about teaching: A fourth set of boundary objects involved concepts and research-based findings about teaching and student learning presented during the professional development course. These concepts addressed issues, such as student engagement, mobilizing students' prior knowledge, the importance of having clear lesson goals, how to stage these goals, and how teaching relates to assessment practices. These conceptual notions were offered as optional resources in discussing and reflecting on teaching and student learning during the PSG activity. In what follows, we describe the research design.

Our study investigated one PSG over a period of six months. The group included four university professors teaching in musicology, medical education, healthcare administration, and social sciences. The data included video recordings of the PSG meetings: preparation meetings, classroom teaching, and feedback discussions. In addition, written data sources included participants' teaching plans and memos, as well as transcripts of individual and group interviews. Table 4 describes our data.

Table 4: Overview of the data

\begin{tabular}{|l|l|l|}
\hline & Data description & Amount/type of data \\
\hline $\begin{array}{l}\text { Background } \\
\text { documents }\end{array}$ & $\begin{array}{l}\text { Task descriptions, conceptual notions, } \\
\text { participants' teaching plans, and PowerPoint } \\
\text { presentations }\end{array}$ & $\begin{array}{l}\text { Procedural descriptions, } \\
\text { lesson plans, and slides }\end{array}$ \\
\hline $\begin{array}{l}\text { Main } \\
\text { documents }\end{array}$ & PSG memos & 4 written documents \\
\hline Video data & $\begin{array}{l}\text { Pre-observation meetings } \\
\text { Classroom observations } \\
\text { Feedback discussion observations }\end{array}$ & $\begin{array}{l}5 \text { hours } \\
6 \text { hours } \\
5 \text { hours }\end{array}$ \\
\hline Audio data & Individual and group interviews & 2 hours \\
\hline
\end{tabular}


The video recordings from PSG meetings represent the main data, while memos in addition to lesson plans, slides and interviews served as background data in our analysis. All the data were collected after informed consent was obtained. While the video data was reviewed entirely for the purpose of providing an overview and selecting representative samples (Braun \& Clarke, 2006), the mediating artifacts and background data such as memos, teaching plans and slides were examined as additional resources that shaped interactions in the group. Alvesson and Sköldberg (2000) inspired this qualitative longitudinal analysis, in which the combination of various empirical sources adds depth to the findings.

Our analytic approach to the PSG discussions started with 16 hours of video data. These video recordings were transcribed including annotations for nonverbal gestures and use of objects (Jordan \& Henderson, 1995). Based on this material, we reviewed the data and selected a range of episodes to create an impression of how the participants engaged and made sense of each other's teaching practices. Finally, we selected a sample of episodes we considered representative of these conversations. These episodes display two of the PSG members with similar teaching tasks and student population, allowing a comparative view of the PSG discussions.

Our approach to analyzing the discussions was based on identifying how the participants oriented themselves within an unfamiliar activity. The discussions analyzed center on figuring out how to contribute productively with experiences and insights from the participants' own practices, and the role provided by mediational artifacts, as boundary objects, in these discussions. In capturing the type of talk in discussions, we used Mercer's $(1995,2000)$ three-part typology of disputational, cumulative, and exploratory talk. Disputational talk is characterized by disagreement and individualized decisionmaking with few attempts to pool resources or offer constructive criticism. Such talk is often based on short assertions or counter-assertions and is characterized by competitive 
relationships, rather than sharing and resolving different opinions. Hence, in disputational talk “...although a lot of interaction may be going on, the reasoning is very individualized and tacit" (Mercer, 1995, p. 21). Cumulative talk is interaction in which participants build positively, but uncritically, on each other's utterances. Here, talk is used to create mutuality through confirmation and elaboration, with implicit focus on "...maintaining solidarity and trust, rather than seeking the best possible outcome" (Mercer, 1995, p. 21). The focus in this kind of conversation is marked by joint decisions without really challenging each other's utterances. Exploratory talk occurs when parties engage in critical, but constructive dialogue, or co-reasoning. Here the participants challenge and counter-challenge each other by including justifications and alternative notions. Compared with the other types, exploratory talk is more accountable given the explicit evaluation of utterances during the discussion. Agreements are often embodied as constructive criticism, justified proposals, and deepened insight with collaborative learning as a potential outcome (Littleton \& Mercer, 2013). We used these three types of talk to analyze the PSG discussions.

\section{Findings: Analyzing PSG discussions}

Below, we describe two cases with interactional sequences displaying the teaching of Andrew and Kate who were in the process of developing their own seminars and lectures in their respective programs. The interactional episodes show a combination of discussions from the pre-observation meeting and the feedback discussions. Our focus in the following analysis is to illustrate how the group members made sense of the presented teaching sessions and how artifacts as boundary objects surfaced and resurfaced during these discussions. We also focus on how the participants build on each other's contributions with reference to Mercer's (2000) typology.

\section{Case 1-Andrew}

Extract 1 starts with Andrew describing his teaching to the group in the pre-observation. 
Andrew is in the beginning of his description, while the other members are looking at and taking notes on a printout of Andrew's memo.

\section{Extract 1}

1 Andrew Yes, I will be giving a lecture on a ... it is what we call a practical-theoretical subject. (...) These are primarily for the first-year students, but open for others, so there will be a few second- and third-year Bachelor's students there as well. Well ... in this subject they will be doing practical work —-the students. It is ... they will challenge their own ideas about what music is, and ... work a bit with creating music in new ways. They will learn a lot about technology used in creating music...

2 Sarah (Nods)

3 Andrew It is ... in this specific lecture, we will be talking about sensor technology...

4 Sarah (Nods)

5 Andrew And there are different aims for what the students are supposed to learn. They will gain an overview and learn how to categorize different types of sensors, and $\ldots$ yes ... reflect .... to have a certain level of reflection on what types of sensors, what sensors fit different types of interactions...

6 John Can I just interrupt?

7 Andrew Yes.

8 John Because I don't really understand... What is a sensor?

In Extract 1, Andrew starts describing the overall course in musicology, which is a mixture of lectures, seminars, and workshop sessions. In line 3, Andrew describes the particular lecture the PSG is going to observe and give feedback on. Andrew continues to detail the topic of this lecture, which is about sensor technology. He starts elaborating on aims, such as students reflecting about types of sensors and properties of sensor interaction. While Andrew describes his session to the group, participants listen and confirm sporadically through gestures and oral confirmations until he is interrupted by John, in lines 6-8, who asks, "What is a sensor?" 
John's statement, “I don't really understand...” in line 8, represents a turn. John interrupts the description, announcing his unfamiliarity with Andrews's teaching topic, who is challenged to explain this further. In this way, the statement represents a disturbance in which one of the participants explicitly states he is not able to make sense of the discussion. In the following extract, immediately following John's question, Andrew addresses this query.

\section{Extract 2}

9 Andrew A sensor is ... for example, the unit inside your cell phone that measures if you hold the phone like this or this (picks up his phone and turns it around)

10 John Okay.

11 Peter (Nods)

12 Andrew So it is a tool for measuring ... like, a camera is also a sensor..

13 John $\quad$ Mmm

14 Andrew ...that measures light coming into

15 John Yes, I see.

16 Andrew Yes, and we use this when producing instruments.

17 Peter Mmm

18 Andrew And this is what they learn about in this course.

19 John $\quad$ But I do not understand how .

20 All (Laughs)

21 Andrew You ... you will see some examples.

In line 9, Andrew attempts to explain what a sensor represents in his particular teaching session. He demonstrates this by showing how his cell phone reacts to movements due to electronic detectors or "feelers" in the phone. But in line 19, John continues by stating that he still does not understand. At this point, Andrew discontinues explaining and, instead, refers to the upcoming teaching session. Extract 3 shows another interesting turn when Kate pursues the issue. 


\section{Extract 3}

22 Kate But, if they don't know what a sensor is ... can they just start by picking up their cell phones and $\ldots$

23 Peter (Laughs)

24 Andrew Yes, they could.

25 Kate "This is a sensor." So, it is about touching and feeling something in your hands ... to feel ...

26 John Yes.

27 Andrew Yes.

28 Kate $\quad .$. what it is.

29 Peter Mmm

$30 \mathrm{John} \quad$...like in movement and music (...) or, as you said (prior to this excerpt), a way to create instruments.... I think I understand now. Well, I still don’t really understand; this is new to me, but how do you make a music instrument based on technology? Is it about .... like simulating a known instrument or is it about creating something completely new?

31 Andrew It could be, or they might accomplish more if they create something new.

32 Peter Sounds very open-ended... (...)

33 Andrew It is. Is it too much?

In Extract 3, Kate enters the conversation by referring to the cell phone as a possible mediating artifact. She refers to it as an object for helping students understand through inclass demonstration. John joins in again in line 30 and elaborates Kate's contribution: he now understands the general notion of sensor, and also asks for more information. Peter's comment in line 32 emphasizes the concept as general, and the excerpt ends with Andrew asking if he is approaching this topic too openly in his teaching.

Together, the three extracts contain several interesting elements. The first extract starts in a cumulative manner: Andrew explains uninterrupted while the others give approving and supportive signals. The group does not contribute with explicit elaborations, but their behavior is confirmational, which is typical of cumulative talk. A turn occurs at the end of the 
first and beginning of the second extract: John requests more information about Andrews's teaching. His question is not directed toward the trustworthiness of the content, but how the content is communicated pedagogically; i.e., if John does not understand, how can students be expected to understand? Andrew's reaction to the question is to further explain, using different words and using an artifact to mediate the meaning of his message.

Regarding how the discussion explores the topic, John's question appears to resemble disputational talk. As Andrew elaborates his explanation with an example of what a sensor is with his mobile phone, John does not engage with alternative assertions. Another interesting feature in Extract 2 is that Andrew acts as a "broker" using the mobile phone to demonstrate principles of his own discipline. This may be considered an attempt to introduce elements from his discipline into the cross-disciplinary PSG. Here we see how difference is explicitly surfacing in the PSG setting,with a clear attempt to bridge the gap.

A new turn occurs in Excerpt 3 when Kate joins the discussion in an attempt to clarify. She introduces both an elaborated description and a suggestion for how to use the mobile phone as a mediating artifact in Andrew's class. This appears constructive, resembling exploratory talk. Simultaneously, the mobile phone appears as a boundary object for the PSG discussion, as well as a possible resource for Andrew in teaching his students.

In summary, the extracts display an episode of boundary interactions in which the participants are creating sameness across diverging understandings and assumptions about a disciplinary topic. Through this discussion, the participants negotiate an agreement in which Andrew is both made aware of the challenges his own students might be facing, as well as introduced to the idea of using the cell phone in class. Although an incremental step, using the phone as an artifact in class may have explanatory value for the students and their learning of the subject. As our classroom observations confirm, Andrew used his phone to demonstrate and explain digital sensors to his students. 


\section{Case 2 - Kate}

While Andrews's case illustrates a series of extracts in one episode from the preobservation meeting, Kate's case draws on talk from the pre-observation meeting and feedback discussions. In this way, we trace points made across PSG sessions. To begin, Kate explained to the group in the pre-meeting what this course means to her (see Extract 4).

\section{Extract 4}

1 Kate It is really exciting that you will be there for this lecture because this is the first lecture in the course, and it is the first course I have been involved in designing. ( ...) Earlier this was a course in organizational psychology, but I have taken it into the direction of work life and the welfare state, themes that are some of the most boring stuff that young people can imagine. $(\ldots)$

2 Andrew (Laughs)

3 Kate But I find it extremely exciting and very important. I have a sense of being on a mission here ... helping people understanding that the welfare state is and how it shapes important parts of our society. (...) My goal is to make people think that this theme is a bit exciting and important. And I also think that it is a bit important to set the tone for the entire lecture series.

In Extract 4, Kate considers her teaching, the responsibility related to it, and the challenges she is facing. She also describes the timing of the lecture to be observed by the PSG.

At the end of these introductory statements and a few moments later, her focus shifts to addressing a particular aspect that she described in her memo distributed to the group prior to the meeting (see Extract 5).

\section{Extract 5}

23 Kate There is something that I really wonder about (...). I really would like to have some feedback on the dramaturgy and how I fill the role as a teacher. Well, it is the first time I am responsible for the course, so I don`t know it very well. But this is also about what kind of relation I want to have to them [the students] and...

24 Peter $\quad$ Mmm 
25 Kate ...I believe that there is a lot of anxiety at the university about this, which I am genuinely concerned with, and that is that it [the students] must be allowed to ask silly questions.

26 Andrew Mmm

27 Kate I consider this very important!

28 All Mmm

29 Kate I..., I sat there - for so many years myself without daring to ask those silly questions (laughs) ... so I really want to contribute to this

30 Andrew I recognize myself in this, a lot - in that dramaturgical part.

31 Kate Yes?

32 Andrew I had the same now ... on the ... in my course last week. I wanted everybody to introduce themselves. I was introducing myself, it is about ... about just like you say, it is about how you get somebody started.

33 Kate Mmm

34 Peter But how do you .... How can you fill the role as a teacher, I mean to make the group of students feel safe? You will have to do that early, right? It is a challenge.

35 Kate Yes, and a dilemma too because it has to do with taking ownership in the room to make yourself interesting.

36 Peter Mmm

37 Kate But the more you take the room yourself, the more the others keep sitting in their chairs, right?

38 Peter Mm, mmm

39 Kate Well it is, I think, a rather difficult balance ...

40 John Well, I think that you should start with a catching story, "This is about the welfare state; there are many discussions about that nowadays."

In Extract 5, Kate introduces an issue of importance to her: to make students feel safe to ask "silly" questions. This inclusive impetus is also stated in her memo and, in this extract, she invites her peers to discuss the matter openly. Kate also refers to the notion of dramaturgy, which is a concept explained during the introductory course, to illustrate how a teacher must have a clear purpose and set the stage for their students, as well as a have sense of how to 
enact their role as a teacher. This concept does not prescribe specific roles or ways of acting, but an awareness of how teachers often implicitly approach their teaching. Often teachers focus on their need to cover content, rather than think through the goal for the session and reflect on how the enactment of the teaching role influences how their students act. Kate draws attention to how she might act, to create a safe atmosphere for students to "... ask silly questions." In line 29 and onwards, the participants contribute their perspectives, starting with Andrew, who confirms Kate's statement and refers to his own experiences, while Peter addresses the complex balance between a teacher's role and students' participation. At the end of the extract, John offers an idea about how to capture students' attention, referring to Kate's concern about the teaching topic being boring. This input moves the focus away from Kate's presented dilemma.

About a minute after the extract above, Kate returns to the issue as seen in Extract 6 .

\section{Extract 6}

62 Kate Well, what I think would be very unfortunate is if the lecture series ends up with an expectation from the students that ... well that they sit there and expect me to talk to them for two hours.

63 Peter So, you want to make a clear invitation, to activate...

64 Kate Yes, Mmm...

65 Andrew Right, so it is this including thing that is your main ....

66 Kate Well, I think it is important that it (the lecture) appears a bit like a seminar too, not just a passive lecture. Yes! (....)

67 Andrew Well, then I believe that John`s comments about this, about what you could do...

68 Kate Mmm, Yes.

69 Andrew Would it be okay to give students some influence in deciding the content of the lecture series? Or would that be a bit scary? Could you, I mean if there are any themes or questions that would be engaging to them ... could you then allow them to ...

70 Kate Well, the syllabus and the themes are kind of ...

71 Andrew Yes.

72 Kate ...kind of decided upon, but of course you could challenge them to draw in relevant stories 
In Extract 6, Kate returns to the issue of how to involve students. This is confirmed by Peter and Andrew as Kate elaborates further in line 66. In line 69, Andrew contributes with another suggestion of allowing students to have an influence on the content, to which Kate responds reluctantly, but offers a way for them to "draw in" relevant stories from their own lived experiences.

After this extract, the discussion continues addressing other issues, and ends with a suggestion of implementing buzz groups in Kate's lecture. A buzz group is a practical activity designed to involve students more actively that was introduced during introductory course; therefore a familiar concept to the PSG members. At the end of this pre-observation, Kate decides to try buzz groups in her lecture.

In the final extract below, we enter the feedback discussion after Kate's lecture, which took place over a week later. The discussion begins with Peter's feedback as the main supervisor.

\section{Extract 7}

Peter: $\quad$ You asked two questions [in your memo]. The use of PowerPoint, [if you were] relaxed enough, and [if you] encouraged the students to talk. I think it was those two....

Kate: $\quad \mathrm{Mmm} .$.

Peter: The main points that you had at the end of that presentation worked fine, I think. And yes, it was relaxed enough! And the buzz groups that you used worked well. I noticed that you managed to engage the students. The only thing is—what you could have tried—was to make that engagement last... in some way.

Kate: $\quad$ Mmm...

Peter: $\quad$ But I don't know how you could have done that, but I noticed that at one point there was momentum.

Kate: $\quad$ Mmm...

Peter: $\quad$ Because the thing is... this is a kind of topic where you really can engage people, you notice that. 
Kate: $\quad$ Mmm...

Peter: $\quad$ At the same time, you will have to use the role as a conductor because it can spin away in many, many directions. But I think those buzz groups worked very well. You are nice, relaxed, and engaged and so on - the right approach as I see it. The only thing that I missed was a bit on ... what are the students supposed to end up with? I mean, after the lecture?

$(\ldots)$

John: Well, I have noticed some of the same things [as Peter]. [Pointing at memo]. When you started, well, I expected that you were going to bring on a real teaser as a start. "The welfare state is threatened," "The migrants are coming," right? Or...

Peter: $\quad$ (Laughs]

Kate: $\quad($ Laughs]

John: Right? That's exactly what we discussed [in the pre-observation meeting].

Kate: $\quad$ Mmm...

Extract 7 begins with Peter referring to Kate's memo with her written lesson description. He also refers to his observations of the buzz groups and comments on the issue of student engagement, which was discussed in the pre-observation. The talk in this part of the extract can be characterized as a monologue with Kate's confirmatory responses, "Mmm." This pattern of talk follows the procedural description (Artifact 2) of appointing a main supervisor for each teaching session. In this case, Peter fills this role, with the responsibility of starting the feedback session. When John enters the conversation later, he confirms Peter's comments, and also addresses other issues raised during the pre-observation.

As an overview of Kate's case, the Extracts 4-7 involve a range of boundary-crossing efforts. The narrative in this case displays how the PSG discusses three main issues: (a) making a subject interesting and motivating for the students; (b) how to involve students actively in teaching; and (c) the difference between setting out with a clear goal versus 
sharing control by involving students and letting them be more in charge of their learning.

These issues continuously reentered the discussions across PSG sessions.

The dilemma raised in Extract 5 between shifting from teacher-centered to more student-centered pedagogy was both discussed in pre-observation and, in part, addressed with buzz groups: involving students without losing attention to the lecture. Peter's feedback notes that this attempt was successful, but not necessarily resolved the dilemma since it was unclear "...what the students are supposed to end up with." Here, the feedback discussions continue with boundary interactions addressing this practical teaching dilemma. In these discussions, concepts from the introduction course (Artifact 4) are taken up and used to incorporate clear goals, "buzz groups," and student engagement. These concepts emerge in the discussion without further request for clarification, an indication of effortless boundary interactions between the participants.

Kate's memo also mediates the discussions (Artifact 3 ) in defining a focus for preobservation and feedback. In the last session, the memo emerges in Peter's feedback by direct reference (Extract 7), functioning as a point of departure for the whole discussion. Throughout the video, also the other participants physically point at the memo while stating their comments. This kind of direct reference to the memo is representative of the other participant cases in the PSG.

Regarding the type of talk, in the pre-observation discussion (Extract 5) the talk can be labeled as cumulative, in that Andrew builds on Kate's ideas by referring to his own experiences. The discussion moves toward exploratory talk, as Andrew justifies his contribution conceptually with reference to the notion of the dramaturgy. Moreover, Peter enters the conversation in an exploratory way by engaging critically in discussing the dilemma reflectively and constructively. This exploratory feature continues in Extract 6, when Kate states her concerns more clearly, the others contribute with suggestions, and Kate again 
responds critically in a contemplative manner. The further discussions in these preobservations also appear exploratory, ending with Kate choosing an experimental approach to her lecture. Finally, the talk in the feedback discussion appears exploratory in that both Peter and John respond critically in a constructive way by underlining the successes and also pointing out possibilities for further improvement.

In sum, both cases demonstrate that pedagogical, rather than disciplinary, aspects are discussed in the sessions, illustrating that the PSG offers a boundary zone for discussing teaching across disciplines and practices. In the follow-up interviews conducted for this study, the group members were asked to reflect further on these aspects. Their responses largely confirm our findings. For example, Andrew stated:

Andrew: What I have learned most about is how to include students during a lesson-simply to have an open dialogue all the way through and ask [the students] a bit about the things we are working on, and to reconsider my own arrangements all the time.

Beyond this enhanced awareness of student involvement, awareness of the purpose of each teaching session was underscored when Kate stated:

Kate: Something I have become more conscious about is to reflect thoroughly about the object of the lesson. What is it that I want to communicate to my students in this specific lesson? Now I approach it more from that angle and not only, "This is the syllabus, and I have to make sure that I cover it all."

Here, Kate notes that the specific aims and purposes of each teaching session often remain implicit to the teacher, creating a challenge for students to follow lessons. Working with teachers from other disciplines was an eye-opener, as this implicitness was challenged by the group. In this sense, valuable awareness was gained in allowing peers from other disciplines without content expertise to enter as "observing students."

As noted previously, boundary zones can create spaces that are generative given the value of difference perspectives. Boundary zones highlight how productive interactions can 
emerge from difference, rather than overcoming or avoiding them (Scaratti, Ivaldi, \& Frassy, 2017; Akkerman \& Bakker 2011). Although this experience of sameness based on difference was considered largely positive, weaknesses were also noted. As one example, Kate stated:

Kate: Even though it was useful and fun, we were quite nice to one another. There was a lot of positive feedback. There were also some things that they noticed and commented upon, which is useful to bring on. But there wasn't really much critique... more like how they see things from an external point of view... These kinds of things are interesting to hear because you do not see yourself from the outside like they do.

Here, the PSG discussions are described as friendly and with little friction, a statement which is representative of the group. While Kate still describes the PSG as useful "external point of view," the question is whether the participants were sufficiently challenged. Another aspect mentioned in the interviews was the intimacy of entering each other's teaching, as when Andrew stated: "It has been demanding. In a sense, you're being pushed out on thin ice. You are being exposed to colleagues, and not 'only' students." All the participants confirmed this feeling of being exposed by having peers in class, as Andrew noted, people "who you really do not know very well" scrutinizing lessons. The fact that peers come from other disciplines is identified as testing, but also a valuable opportunity for sharing different perspectives and insights.

\section{Discussion}

The first research question in our study asked: what significance do the implemented boundary objects hold in the PSG discussions? Four main boundary objects were used: Artifact 1, the temporal sequencing of PSG sessions, Artifact 2, defining tasks and roles, Artifact 3, teaching memos, and Artifact 4, conceptual notions about teaching relevant across disciplinary boundaries. Our analysis revealed that the temporal PSG sequence (Artifact 1) accommodated boundary-crossing by creating spaces for reflection. We also found that the conceptual resources introduced in the faculty development course (Artifact 4) frequently 
recurred during these discussions; "like dolphins, coming up now and again to the surface, and in doing so revealing the underlying continuity of the talk" (Mercer, 1995, p. 33). These conceptual “dolphins" reflected concepts_-including engaging students during teaching, having clear lesson goals, and facilitating these goals_-identified through the feedback discussions. These discussions varied between cumulative talk, which refers to “individualized sense-making” (Mercer, 1995, p. 104), and exploratory talk, characterized by participants challenging each other, asking for reasons, and exploring alternative ideas. In the examples of exploratory talk, the participants not only shared opinions, but also gave conceptually based reasons and pointed out alternative approaches, thus illustrating how the concepts (Artifact 4) contributed to a discursive sameness accommodating a shared view in the group (Tsui \& Law 2007). The continuous references to the memos (Artifact 3) served as a common discursive denominator (Abraham et al., 2015).

The second research question asked: what obstacles and opportunities emerge in this PSG arrangement? The data illustrate that the mediating artifacts were only gradually appropriated as boundary objects by the participants. Hence, as they became familiar with the procedure, they also increasingly engaged in an exploratory manner. Exploratory talk is related to deeper gains in learning outcomes in Mercer's (2000) three-part typology of talk. The participants emphasized that these reflective experiences were highly fruitful for their teaching, which also corresponds to previous research studying feedback as social and dialogic acts (Ajjawi \& Boud, 2015; Thomas et al., 2014), presupposing both situated relevance and taking the participants' own experiences and beliefs deeply into account.

Even though exploratory talk emerged in the discussions, this shared involvement only appeared sporadically, and mainly toward the end of the group sessions. Therefore, even if the PSG participants themselves maintain that they benefitted from the activity, the potential may only be partially exploited. The appropriation of the mediating artifacts, therefore only create 
sameness in a weak sense (Lambert, 2003b; Tsui \& Law, 2007). This result may necessitate an artifact re-design in which shared meaning through exploratory talk is more easily and effectively achieved (Scaratti, Ivaldi, \& Frassy, 2017).

Finally, the analysis showed that the participants held friendliness and politeness in high regard — so high that it may have been a hindrance to critical and honest feedback. This indicates that the PSG procedure may need to be re-designed in a way that better enables the members to develop their comments toward more exploratory talk (Mercer, 2000). A crucial aspect in realizing this potential is to create trust among PSG members, a process that takes time to develop. Here, trust relates to the creation of the boundary zone of sameness, which is developed together by the participants over time. While the mediating artifacts might be more oriented toward creating trust, the boundary zone of the PSG is also made more vulnerable given openness, honesty, and exposure. In further developing the PSG framework, this balance between openness and vulnerability needs to be carefully considered.

\section{Conclusions}

In this paper, feedback discussions are conveyed as a collaborative process accommodated by boundary objects. This deeply relational process emerged not despite of, but rather, because of the participant's diverse disciplinary perspectives. In this way, the crossing of disciplinary boundaries created opportunities for, sharing, and gaining new insights about teaching practices that resemble previous findings on peer-based feedback practices on teaching (Costa \& Callic, 1993; Ferrado, 2000; Kohut, Burnap, \& Yon, 2007). A limiting aspect in this respect is that PSG discussions tend to be overly friendly and not sufficiently challenging the participants. A more explicit focus on how to shift PSG members from using polite, or cumulative talk, to exploratory talk should, therefore, be considered.

It is also unclear, whether the individual gains of the PSG members will affect innovation within the participants' respective teaching communities. This limited innovative 
spread suggests further potential of developing the PSG procedure on a more collective level. To explore this potential further, we suggest two main lines of future inquiry.

One area to examine may be to conceptually sensitize the value of difference. While the term boundary relates to sociocultural difference, the notion of boundary zones and objects refer to dialogue and social interaction across established communities. Conceptually, this allows for observing how people and resources move between different practices. Simultaneously, the concept of a boundary zone needs to be distinguished from boundary crossing, which represents a transition across communities and, how influences from the outside contribute to change. While highly relevant to the focus of this article, the process of crossing is not easily captured. This is partly due to the complexity of how people move between practices, and partly because boundaries often are hard to define (Rantavuori, Engeström \& Lipponen, 2016). It is therefore important to note that while the notion of boundary is of analytic value, the limitations of capturing the complexities of lived social life are still prominent and in need of further empirical and analytic exploration (Akkerman \& Bakker, 2011).

Further research is also needed to better map an analytic space for exploring how the value of difference can contribute to new and improved approaches to teaching formed collectively. It is problematic to decide to what extent the experimental efforts in the PSG may contribute to the teaching practices of other colleagues in their respective teaching communities. Thus, while it is difficult to determine whether this study represents a recycling of established teaching approaches for other colleagues, for us this approach represents an opportunity for truly creative work on a collective scale. Therefore, the role that creativity can play in developing PSG outcomes in boundary zones - as sites where differences are explicitly valued - deserves more in-depth examination. 


\section{References}

Abraham, R., Aier, S. \& Winter, R. (2015). Crossing the Line: Overcoming Knowledge Boundaries in Enterprise Transformation. Business \& Information Systems Engineering,57(1), 3-13.

Ajjawi, R. \& Boud, D. (2015). Researching feedback dialogue: An interactional analysis approach. Assessment \& Evaluation in Higher Education, 42(2), 252-265.

Akkerman, S. \& Bakker, A. (2011). Boundary crossing and boundary objects. Review of Educational Research, 81(2), 132-169.

Alvesson, M. \& Sköldberg, K. (2000). Reflexive methodology: New vistas for qualitative research. London: Sage Publications.

Bransford, J. D., Brown, A. L., \& Cocking, R. R. (2000). How people learn. Cambridge, MA: National Academy Press.

Braun, V. and Clarke, V. (2006) Using thematic analysis in n psychology. Qualitative Research in Psychology, 3(2), 77-101.

Costa, A. \& Kallick, B. (1993). Through the lens of a critical friend. Educational Leadership: Journal of the Department of Supervision and Curriculum Development, 51(2), 49-51.

Curlette, W. L. \& Granville, H. G. (2014). The four crucial Cs in critical friends groups. The Journal of Individual Psychology, 70(1), 21-30.

de Lange, T. (2011). Formal and non-formal digital practices. Institutionalizing transactional learning spaces in a media classroom. Learning, Media \& Technology, 36(3), s 251275.

de Lange, T. \& Lauvås, P. 2018. «Faculty Peer Mentoring in higher education - an analysis of peer conversations." UNIPED 41(3), 259-274.

Donnelly, R. (2007). Perceived impact of peer observation of teaching in higher education. International Journal of Teaching and Learning in Higher Education, 19(2), 117-129. 
Engeström, Y. (2015). Learning by expanding: An activity-theoretical approach to developmental research (2nd ed.). New York: Cambridge University Press.

Engeström, Y. \& Sannino, A. (2010). Studies of expansive learning: Foundations, findings and future challenges. Educational Research Review, 5, 1-24.

Ferrado, J. M. (2000). Reflective practice and professional development. ERIC Clearinghouse on Teaching and Teacher Education. Washington DC: ERIC Digest.

Hammersly-Fletcher, H. L. \& Orsmond, P. (2005). Reflecting on reflective practices within peer observation. Studies in Higher Education, 30, 213-224.

Jahreie, C. F. \& Ludvigsen, S. (2007). Portfolios as boundary object: Learning and change in teacher education. Research and Practice in Technology Enhanced Learning, 2(3), 299-318.

Jordan, B \& Henderson, A. (1995). Interaction Analysis: Foundations and Practice. Journal of the Learning Sciences, 4(1), 39-103.

Kohut G. F., Burnap, C., \& Yon M. G. (2007). Peer observation of teaching: Perceptions of the observer and the observed. College Teaching, 55, 19-25.

Konkola, R., Tuomi-Gröhn, T., Lambert, P., \& Ludvigsen, S. (2007). Promoting learning and transfer between school and workplace. Journal of Education and Work, 20(3), 211228.

Lauvås, P., Lycke, H. K., \& Handal, G. (2016). Kollegaveiledning - med kritiske venner.

[Peer Mentoring - with critical friends] Oslo: Cappelen Damm Akademisk.

Lambert, P. (2003a). Promoting developmental transfer in vocational teacher education. In T. Tuomi-Gröhn \& Y. Engeström (Eds.), Between school and work: New perspectives on transfer and boundary crossing (pp. 233-254). Amsterdam: Pergamon. 
Lambert, P. (2003b). Boundary-crossing place as a tool for developmental transfer between school and work. In F. Achtenhagen \& E. G. John (Eds.), Milestones of vocational and occupational education and training (pp. 181-216). Bielefeld: Bertelsmann.

Littleton, K. \& Mercer, N. (2013). Interthinking: putting talk to work. London: Routledge.

Martin, E., Prosser, M., Trigwell, K., Ramsden, P., \& Benjamin, J. (2000). What university teachers teach and how they teach it. Instructional Science, 28(5), 387-412.

Mercer, N. (1995). The guided construction of knowledge: Talk amongst teachers and learners. Clevedon: Multilingual Matters LTD.

Mercer, N. (2000). Words and minds: How we use language to think together. New York: Routledge.

Price, M., Handley, K., \& Millar, J. (2011). Feedback: Focusing attention on engagement. Studies in Higher Education, 36(8), 879-896.

Rantavuori, J., Engeström, Y. \& Lipponen, L. (2016). Learning actions, objects and types of interaction: A methodological analysis of expansive learning among pre-service teachers. Frontline Learning Research, 4(3), 1 - 27.

Roos, A. (2012). Activity theory as a theoretical framework in the study of information practices in molecular medicine. Information Research, 17(3), 6-16.

Scaratti, G., Ivaldi, S., \& Frassy, J. (2017) Networking and knotworking practices: Work integration as situated social process. Journal of Workplace Learning, 29(1), 2 23.

Steen-Utheim, A. \& Wittek, A.L. (2017). Dialogic feedback and potentialities for student learning. Learning, Culture and Social Interaction, 15, 18-30.

Thomas, S., Chie, Q. T., Abraham, M., Raj, S. J., \& Beh, L. S. (2014). A qualitative review of literature on peer review of teaching in higher education: An application of the SWOT framework. Review of Educational Research, 84(1), 112-159. 
Tsui, A. B. M. \& Law, D. Y. K. (2007). Learning as boundary-crossing in school-university partnership. Teaching and Teacher Education, 23, 1289-1301.

Vygotsky, L. S. (1987). Thinking and Speech. In R. W. Rieber \& A. S. Carton (Eds.), The collected works of L.S. Vygotsky (Vol. 1). The development of Vygotsky's thought: An Introduction (pp 1-16). New York: Plenum. 